\title{
TRADISI SUWUK DALAM TINJAUAN SAINS MODERN
}

\author{
Achmad Zuhdi Dh \\ Universitas Islam Negeri Sunan Ampel Surabaya, Indonesia \\ E-mail: zuhdidh@gmail.com
}

\begin{abstract}
For Javanese, one way to cure the sick is to do suwuk (jampi). Sumuk tradition, namely healing by reciting mantras (certain readings) that are blown on the crown of the patient and sometimes also use water media, especially for some modern Muslims, was initially seen as a healing practice that contains elements of shirk because it was considered not in accordance with the principles of Islamic aqidah. Today, this view begins to change after a normative source has been found from a number of traditions that allow ruqyah that works similar to sumuk. It was also strengthened by the results of experiments and the findings of a number of scientists about the effect of certain readings and the wonders of water. This article will explain the tradition of sumuk which is the same as ruqyah, then elaborate normative sources of the Qur'ān and the Hadith which legalize it and the view of modern science that supports it, so that its existence is still relevant to modernity.
\end{abstract}

Keywords: Sunuk; ruqyah; modern science.

\section{Pendahuluan}

Penelitian tentang penyembuhan alternatif dengan membacakan sesuatu kepada orang yang sakit cukup banyak. Kabul Wibowo, dengan penelitiannya tentang metode dakwah dengan pendekatan ruqyah shariyah, menerangkan bahwa dengan pendekatan ruqyah shariyah dapat membantu kesadaran beragama bagi jamaah majelis zikirnya. ${ }^{1}$ Khainuddin dengan penelitiannya tentang al-Shifä' dalam Tafsir al-Ibriz karya Bisri Musthofa, menjelaskan

\footnotetext{
1 Kabul Wibowo, "Metode Dakwah dengan Pendekatan Ruqyah Syar'iyyah: Studi Kasus pada Majelis Zikir al-Rasuli al-Muhammadiyati al- Haqmaliayati di Desa Bengbulang Kecamatan Karangpucung Kabupaten Cilacap”, dalam KOMUNIKA: Jurnal Dakwah dan Komunikasi, Vol. 13, No. 1 (April 2019).
} 
bahwa al-Qur'ān bisa berpengaruh pada penyembuhan ruhani dan jasmani. ${ }^{2}$ Marzuki, dengan penelitiannya tentang sumuk sebagai pengobatan tradisional pada etnis Jawa, menemukan bahwa praktik suwnk dilakukan orang jawa karena faktor kepercayaan dan latarbelakang ekonomi yang dalam praktiknya cukup dengan modal murah, yaitu menggunakan bacaan-bacaan tertentu disertai media air. ${ }^{3}$ Sementara Muhammad Huda, dengan penelitiannya terhadap kitab Risālät Khulq al-Kirām wa Shifä' al-Ajsäm karya K.H. Moh Sholeh sebagai karya yang bermuatan local wisdom, menjelaskan tentang praktik suwuk yang dibolehkan dan yang tidak dibolehkan menurut Islam. ${ }^{4}$

Sejumlah penelitian yang membahas tentang penyembuhan model sumuk tersebut masih berada pada kisaran praktik sunuk atau ruqyah sebagaimana yang ditemukan Marzuki di atas; termasuk pula temuan Khainuddin tentang pengaruh sunve dalam memberikan kesem-buhan pada penyakit ruhani dan jasmani; Muhammad Huda tentang praktik suwuk yang dibolehkan dan yang tidak dobolehkan; serta Kabul Wibowo tentang pengaruh sunve atau ruqyah yang dapat memberikan kesadaran beragama yang mendalam bagi jamaah majelis zikirnya. Belum ada satupun penelitian yang fokus pada tradisi sumuk maupun ruqyah yang ditinjau secara normatif berdasarkan al-Qur'ān dan Ḥadīth, berikut tinjauan sains modern terhadapnya, baik dari kajian teoritis maupun praktis, berdasarkan hasil eksperimen, sebagaimana yang akan menjadi fokus dalam artikel ini. Untuk kepentingan itu, artikel ini menggunakan model penelitian kepustakaan dengan melacak kitab-kitab tafsir dan hadìth beserta sharb-nya tentang sumvk atau ruqyah, dan buku-buku atau jurnal yang memuat hasil temuan akademisi tentang pengaruh bacaan-bacaan dan keajaiban air dalam proses penyembuhan.

\footnotetext{
${ }^{2}$ Khainuddin, “As-Shifa' Perspektif Tafsir al-Ibris Karya Bisri Mustofa”, dalam Tribakti: Jurnal Pemikiran Keislaman, Vol. 30, No. 1 (2019).

3 Marzuki, "Suwuk sebagai Pengobatan Tradisional pada Etnis Jawa di Desa Naga Jaya I Kecamatan Bandar Huluan Kabupaten Simalungun" (Skripsi-Universitas Negeri Medan, Medan, 2019).

4 Muhammad Huda, "Local Wisdom dalam Kitab Karya K.H. Muhammad Sholeh (Studi terhadap Kitab Risalat Khulq al-Kiram wa Shifa' al-Ajsam)" (Tesis--UIN Sunan Ampel, Surabaya, 2019).
} 


\section{Akar Tradisi Suwuk}

Dalam kamus Wiktionari bahasa Jawa, suwnk adalah japa-mantra sing disēbulake ing èmbun-èmbunan (tulak lèlara lsp), ${ }^{5}$ yakni bacaanbacaan tertentu (semacam mantra) yang ditiupkan pada ubun-ubun pasien dengan tujuan untuk menghilangkan penyakit dan lain-lain. Sunnk adalah suatu penyembuhan alternatif dengan cara membacakan suatu mantra ${ }^{6}$ pada segelas air yang selanjutnya diminumkan kepada seorang pasien. Di kalangan orang Jawa, sumuk diyakini sebagai cara untuk melakukan terapi atau penyembuhan alternatif dari seseorang yang memiliki kemampuan atau keahlian dalam hal penyembuhan, dengan membacakan suatu mantra atau suatu bacaan pada media air, yang kemudian diminumkan kepada seorang pasien atau kepada orang yang sedang menderita sakit. Dalam praktiknya, media yang digunakan dalam terapi sunvk ini, selain menggunakan air putih, terkadang juga menggunakan ludah dari penyuwuk untuk disemburkan atau dioleskan pada bagian tubuh yang sakit.

Dalam bingkai budaya Jawa, tradisi sumuk sudah dilakukan secara turun temurun dalam berbagai tradisi masyarakat Jawa, di mana proses penyembuhannya dilakukan dengan membacakan mantra-mantra dari seseorang yang dianggap ahli, dukun atau tabib, melalui media air yang kemudian diberikan kepada orang yang sedang sakit, baik dengan cara diminumkan, diguyurkan untuk mandi, maupun sekedar dipercikkan. Hingga saat ini, tradisi suwnk ini masih eksis dan bisa ditemui di berbagai tempat dalam berbagai ritual penyembuhan, maupun di tempat-tempat kegiatan terapi alternatif tradisional.

Praktik menyuwuk yang dilakukan orang Jawa biasanya menggunakan media air. Dalam hal ini, Air Zamzam yang berasal dari kota suci Mekah diyakini sebagai air yang paling baik dan paling manjur untuk digunakan dalam suwuk. Kalau Air Zamzam tersebut tidak ditemukan, bisa juga menggunakan air yang berasal dari tadah hujan, atau air sumur di sekitar makam wali, seperti

\footnotetext{
${ }^{5}$ http://jv.wiktionary.org/wiki/suwuk.

${ }^{6}$ Mantra adalah perkataan atau ucapan yang terdiri dari kalimat yang tersusun dan berirama yang dianggap mengandung kekuatan gaib. Dalam Kamus Besar Bahasa Indonesia, jika dikaitkan dengan penawar, maka mantra penawar berarti mantra pengobatan. Tim Penyusun, Kamus Besar Bahasa Indonesia (Jakarta: Balai Pustaka, 1989), 558.
} 
sumur di sekitar makam Sunan Ampel, Surabaya. Kalau semua itu masih sulit diperoleh, maka setiap air putih (air tawar) juga bisa dipakai, bahkan termasuk air mineral kemasan pun bisa juga digunakan. Caranya yaitu penutup wadah gelas (yang berisi air) dibuka kemudian diletakkan di depan penyuwuk, selanjutnya dibacakan mantra atau doa-doa tertentu dan ditiupkan pada air dalam gelas tersebut, selanjutnya diminumkan kepada pasien.

Jika yang menjadi penyuwuknya berlatarbelakang Islam abangan, ' maka mantra atau doa yang dibacakan pada pasien biasanya menggunakan bahasa Jawa kuno disertai simbol-simbol kepercayaan pra-Islam (Hindu dan Buddha), dan terkadang dicampur dengan bahasa Arab (Islam). Dalam hal ini, umumnya mereka berpedoman kepada kitab yang disebut primbon. Sebagai contoh, dalam kitab primbon Betal Jemur Adammakna terdapat keterangan tentang bacaan atau mantra yang dibacakan pada pasien yang terkena penyakit cacar (cangkrangen). Cara mengobati atau menyembuhkannya adalah dengan mengunyah bawang merah (brambang) dan temu (kunci) kemudian disemburkan (di-suwuk-kan) ke matanya yang sakit setiap pagi, tapi kunyahan yang disemburkan tersebut hanyalah udaranya atau hawanya saja, sehingga kunyahan tersebut tidak sampai mengenai matanya. Adapun mantra yang dibacakan adalah sebagai berikut:

Bismillāhirrahmānirrahīm, kanjul ngaras, kanjul ngalam, Bagus karang aja perak-perak marang aku, pan aku anak putune Sayid Pangeran. Bujang Galiman aja uruk sudi gawe marang aku, pan aku anak putune Bagus Karang. Loncang-Lancing Nyai Rara Kidul aweh gabag cacar plenting 10, 9, 8, 7, 6, 5, 4, 3, 2, 1 siji bae trima, trima saking kersaning Allah. ${ }^{8}$

Berbeda jika yang menjadi penyuwuknya adalah seorang kiai atau ustaz yang memahami al-Qur'ān dan Sunnah, maka yang menjadi mantra atau doa yang dibacakan adalah bacaan-bacaan alma'thürah seperti surat al-Fātiḥah atau ayat-ayat al-Qur'ān lainnya dan doa-doa yang berasal dari nabi. Secara umum, doa yang biasa

\footnotetext{
7 Golongan abangan atau Islam Kejawen adalah orang Jawa yang meskipun ia penganut agama Islam, tidak begitu saleh dan alim, tidak begitu sungguh menjalankan agama, bahkan mereka tidak perlu salat Jum'at, berpuasa, dan lainlain. Kelompok ini terbagi menjadi dua, yaitu wong cilik dan priyayi. Rosihan Anwar, Demi Dakwah (Bandung: Al Ma'arif, 1976), 5.

8 Kanjeng Pangeran Harya Tjakraningrat, Kitab Primbon Betaljemur Adammakna (Yogyakarta: Soemodidjojo Mahadewa, 1980), 53.
} 
dibacakan kepada seorang pasien, selain bacaan surat al-Fātiḥah, adalah doa-doa yang diajarkan oleh nabi seperti: Allähumma rabb alnās mudhbib al-ba's ishfi anta al-shäfí là shäfiya illà anta shifä'an là yughädir saqaman (Ya Allah, Tuhan Pencipta Alam dan Pemelihara Manusia, yang bisa menghilangkan penyakit, sembuhkanlah ia. Engkaulah yang menyembuhkan. Tiada kesembuhan kecuali kesembuhan dari Engkau, kesembuhan yang tidak meninggalkan penyakit sama sekali) (H.R. al-Bukhārī, No. 5410).

Dalam sejarahnya, tradisi sunnk tidak lahir begitu saja di Indonesia. Dahulu, ketika Walisongo melaksanakan dakwahnya, salah seorang anggotanya, yakni Mawlānā Ishậ yang berasal dari Samarkand, Rusia bagian selatan, merupakan seorang ahli pengobatan tradisional. Salah satu metode pengobatan yang dilakukan Mawlānā Ishāà adalah dengan cara melakukan sumuk. Metode suwnk ini menjadi salah satu alternatif dakwah Mawlānā Ishạāq dengan cara memberikan pengobatan secara gratis kepada warga disetiap daerah yang disinggahinya. Suatu saat Mawlānā Ishạāq harus menghadap kepada seorang raja di Blambangan, Jawa Timur, yang saat itu anaknya sedang mengalami sakit keras. Atas izin Allah, pengobatan dengan cara sumuk yang dilakukan oleh Mawlānā Ishạa ini berhasil menyembuhkannya. Sunvk biasanya dilakukan oleh para kiai yang dikenal sangat wira', zubd, atau mereka yang mendalami ilmu-ilmu ketabiban. Dahulu, hampir semua kiai membekali dirinya dengan ilmu sumuk, untuk dakwah dan menambah kharismanya. Biasanya para kiai yang memberikan pengobatan model suwuk ini menyertakan pesan: "Jangan lupa memohon kesembuhan kepada Allah, karena yang punya kekuasaan untuk membuat orang jadi sehat dan sakit hanyalah Allah. Manusia hanya melakukan ikhtiar, sedangkan obat dan sumuk hanyalah perantara, selanjutnya Allahlah yang menentukannya".

Dewasa ini, tradisi sumuk yang telah mendarah-daging dan diruwat secara turun-temurun itu masih bisa bertahan dan dipraktikkan oleh sebagian masyarakat di Jawa. Di kalangan masyarakat Muslim tertentu, terutama kalangan Muslim modern yang sebelumnya cenderung menolak praktik suwuk, belakangan ini pun mulai bisa menerima tradisi ini karena ada kemiripan dengan ruqyah. Istilah ruqyah kemudian lebih populer dengan istilah sumuk, terutama di kalangan masyarakat abl al-sunnab yang modern. Hal ini bisa jadi disebabkan oleh banyaknya literatur Islam dari Timur 
Tengah yang bersumber dari al-Qur'ān dan Sunnah, serta kitabkitab berbahasa Arab lainnya yang membanjiri masyarakat Muslim Indonesia.

\section{Tradisi Ruqyah dalam Islam}

Ruqyah berasal dari bahasa Arab raqā, raqyan, muqiyyan wa ruqyatan." Ahmad Warson Munawwir menerjemahkan ruqyah dengan 'mantra'. ${ }^{10}$ Hans Wehr, dalam A Dictionary of Modern Written Arabic, menulis bahwa ruquah (jamak: ruqan) berarti "spell."1 Sementara itu, John M. Echols dan Hassan Shadily dalam kamusnya mengartikan spell dengan 'jampi', 'mantra' (sihir). ${ }^{12}$ Selanjutnya, Ibrāhīm Anīs dalam al-Mu'jam al-W asịt mengartikan ruqyah dengan 'perlindungan', 13 dan Ibn Taymìah memasukkan ruquah ke dalam kategori 'doa'. ${ }^{14}$ Pendapat yang terakhir ini dikuatkan oleh pendapat Ibn al-Qayyim. ${ }^{15}$

Beberapa pengertian yang menjelaskan tentang arti kata ruqyah dari aspek bahasa tersebut memiliki makna yang sama dan saling melengkapi antara satu dengan yang lain; ruqyah bisa dipahami sebagai semacam doa permohonan perlindungan dengan membacakan atau mengucapkan mantra, yakni perkataan atau ucapan yang terdiri dari kalimat yang tersusun dan berirama yang diyakini mengandung kekuatan gaib. Dalam Kamus Besar Bahasa Indonesia, jika kata "mantra" dikaitkan dengan penawar, maka mantra penawar berarti mantra pengobatan. ${ }^{16}$

Secara istilah, ruqyah telah didefinisikan oleh beberapa ulama, di antaranya oleh Ibn al-Athìr, yang mendefinisikan ruqyah sebagai "permohonan perlindungan (jampi-jampi, mantra) yang dibacakan kepada orang yang sedang sakit seperti demam, ketakutan, dan

\footnotetext{
${ }^{9}$ Louis Ma'luf, al-Munjid fì al-Lughah (Beirut: Dār al-Mashriq, 1977), 276.

10 Ahmad Warson Munawwir, Kamus Al-Munawwir Arab-Indonesia Terlengkap (Surabaya: Pustaka Progresif, 1984), 562.

${ }^{11}$ Hans Wehr, A Dictionary of Modern Written Arabic (London: Macdonal \& Evans LTD, 1974), 355.

12 John M. Echols dan Hassan Shadily, Kamus Inggris Indonesia (Jakarta: PT. Gramedia, 1989), 545.

${ }^{13}$ Ibrāhīm Anīs et al., al-Mu'jam al-Wasit, Vol. 2 (t.t.: Dār al-Fikr, t.th.), 367.

14 Ibn Taymīyah, Majmū' al-Fatāwā, Vol. 27 (t.t.: Dār al-Wafā, 2005), 68.

15 Muhammad b. Abī Bakr b. Ayyūb b. Sa'd Shams al-Dīn b. al-Qayyim alJawzìyah, al-Ṭibyān Fì Aqsām al-Qur'ān, Vol. 1 (Beirut: Dār al-Fikr, t.th.), 92.

16 Tim Penyusun, Kamus Besar Bahasa Indonesia (Jakarta: Balai Pustaka, 1989), 558.
} 
penyakit-penyakit lain". ${ }^{17}$ Sedangkan "Abd al-Razzāq mengatakan bahwa "ruquah adalah permohonan perlindungan yang dibacakan pada orang yang terkena penyakit seperti demam, ketakutan (sawan), dan kedengkian, dengan maksud untuk mendapatkan kesembuhan". ${ }^{18}$ Muhammad Nāṣir al-Dīn al-Albānī dengan agak lengkap mendefinisikan ruqyah yang sesuai sunnah sebagai berikut: "Ruqyah adalah suatu doa yang berasal dari al-Qur'ān dan Sunnah yang sahih yang dibacakan (pada orang sakit) dengan maksud untuk mendapatkan kesembuhan". ${ }^{19}$

Dari beberapa definisi mengenai ruqyah tersebut, sekilas ada perbedaan antara yang satu dengan yang lainnya. Ibn al-Athīr dan 'Abd al-Razzāq secara umum mendefinisikan ruqyah sebagai bentuk permohonan perlindungan yang dibacakan pada orang sakit untuk mendapatkan kesembuhan. Namun dalam definisi tersebut belum dijelaskan mengenai sumber bacaan yang harus dibacakan. Sedangkan Muhammad Nāṣir al-Dīn al-Albān̄i mendefinisikan ruqyah dengan doa yang bersumber pada al-Qur'ān dan Sunnah yang dibacakan pada orang sakit untuk mendapatkan kesembuhan. Beberapa definisi tentang ruqvah tersebut saling melengkapi antara yang satu dengan yang lainnya, sehingga dapat dipadukan menjadi definisi yang utuh, yaitu suatu doa atau permohonan perlindungan kepada Allah dengan membacakan suatu bacaan dari al-Qur'ān dan Sunnah yang sahih kepada orang yang sakit atau mengalami gangguan suatu penyakit, dengan maksud untuk mendapatkan kesembuhan dari penyakit yang diderita dan juga mendapatkan perlindungan dari segala marabahaya.

Dalam sejarahnya, ruqyah sudah lama dikenal oleh masyarakat Arab sebelum datangnya Islam. Ruqyah merupakan warisan bangsa Arab sebagai upaya untuk mendapatkan berkah dan permohonan pertolongan kepada Allah. Ruquah sebenarnya berasal dari agamaagama samawi, kemudian di belakang hari diselewengkan oleh orang-orang yang berprilaku sesat ke dalam sihir dan penangkalannya. Mereka mencampur-adukkan ruqyah dengan ucapan-ucapan

17 Ibn al-Athīr, al-Nihāyah Fì Gharìb al-Hadìth wa al-Athar, Vol. 2 (Beirut: alMaktabat al-'Ilmīyah, 1979), 621. Muhammad b. Mukrim b. Manz̄ūr, Lisān al'Arab, Vol. 14 (Beirut: Dār Șādr, t.th.), 331.

18 'Abd al-Razzāq al-Ṣan'ānī, Tafsìr al-Qur'ān, Vol. 8 (t.t.: t.tp., t.th.), 266.

19 Muḥammad Nāṣir al-Dīn al-Albānī, Ḍa îf Sunan al-Tirmidhi, Vol. 1 (t.t.: t.tp., t.th.), 231. 
yang bisa jadi mereka sendiri tidak memahami artinya. Dalam praktiknya, ruqyah juga ditambahkan dengan suatu benda seperti bebatuan, atau potongan-potongan tulang dan rambut hewan. Akhirnya, di kalangan masyarakat jahiliyah, perkara ruquah pun bercampur-aduk. Setelah Islam datang melalui Nabi Muhammad, ruqyah kemudian digunakan untuk terapi dengan menggunakan ayat-ayat al-Qur'ān dan Hadīth berupa bacaan-bacaan doa yang ma'thür melalui sarana doa. ${ }^{20}$

Di masa jahiliyah, ruqyah diartikan sebagai mantra atau jampijampi, yaitu kalimat-kalimat yang dianggap berpotensi mendatangkan daya gaib, atau susunan kata yang berunsur puisi yang diyakini mengandung kekuatan gaib. Dalam praktiknya, mantra dibaca oleh orang yang mempercayainya guna meminta bantuan kekuatan yang melebihi kekuatan natural, guna meraih manfaat atau menolak bahaya. Dalam pengertian inilah, ruqyah diyakini bisa menyembuhkan, baik karena kekuatan ruqyah itu sendiri ataupun bantuan dari jin dan lain sebagainya. Karena pemahaman dan keyakinan yang demikian ini, maka ruquah pernah dilarang oleh nabi. Nabi pernah bersabda bahwa sesungguhnya ruqyah, tamimah, ${ }^{21}$ dan tiwala $^{22}$ adalah perbuatan syirik. ${ }^{23}$ Sehubungan dengan pernyataan nabi tersebut, maka 'Abd Allāh b. Mas'ūd menjelaskan kepada istrinya yang pernah mengalami sakit mata dan sembuh karena diterapi ruqyah oleh seorang Yahudi. Ibn Mas'ūd berkata: "Sesungguhnya cara ruqyah seperti itu adalah perbuatan setan yang menyolok

20 Muḥammad al-Ṭāhir b. 'Āshūr, al-Tạ̣rì wa al-Tanwìr, Vol. 29 (Tunis: al-Dār al-Tūnisìyah, 1984), 359.

21 Al-Tamäim adalah bentuk jamak dari al-tamimah, yaitu suatu jimat perlindungan yang dikalungkan di leher anak untuk penangkal 'ayn. Jika yang dikalungkan itu dari al-Qur'ān, di kalangan ulama ada dua pendapat, ada yang membolehkan dan ada yang tidak membolehkan. Pendapat yang lebih kuat dan aman adalah yang melarangnya. Abū 'Ubaydah Māhir b. Ṣāliḥ 'Alī Mubārak, Ruqyah Syar'iyyah: Gangguan Jin, Hasad, dan 'Ain, terj. Abu Ahmad (Surabaya: Duta Ilmu, 2006), 207.

22 Al-Tiwalah adalah aji-aji pengasihan (jawa: pelet) yang dibuat dan dimaksudkan agar sang suami mencintai istrinya atau sebaliknya. Hai ini termasuk jenis sihir. Șālih b. 'Abd al-'Azīz b. Muhammad b. Ibrāhīm 'Alī al-Shaykh, al-Tambìd li Sharḅ Kitāb al-Tawḥ̂̀, Vol. 1 (t.t.: Dār al-Tawhịd, 2003), 136.

23 Aḥmad b. Hanbal, Musnad al-Imām Aḥmad b. Hanbal, Vol. 6, ed. Shu'ayb alArnowt et al. (Kairo: Mu'assasah Qurțūbah, t.th), 110. 
matanya dengan tangannya, sehingga ketika diterapi ruqyah, orang yang sakit dapat menahan rasa sakitnya". ${ }^{24}$

Meskipun nabi pernah melarang ruqyah, larangan itu tidak serta-merta berlaku pada semua jenis ruqyah. Ruqyah yang dilarang nabi adalah ruqyah yang di dalamnya terdapat unsur syirik seperti yang pernah dilakukan oleh orang-orang jahiliyah dan orang Yahudi. Selama dalam praktik ruqyah tidak dimasuki unsur syirik, maka dibolehkan. Seorang sahabat nabi bernama 'Awf b. Mālik alAshja'î berkata: "Kami dahulu pada masa jahiliyah biasa melakukan ruqyah, kemudian kami bertanya kepada Rasulullah: 'Bagaimana pendapatmu tentang ruquah yang kami lakukan?'. Nabi kemudian meminta kepada al-Ashja'ī untuk ditunjukkan cara melakukan ruqyah, setelah itu nabi menyatakan: "Tidak mengapa dengan ruqyah seperti itu, selama tidak terdapat unsur syirik di dalamnya". 25

Di kalangan kaum Yahudi, dalam praktik ruqyah ada yang bekerja sama dengan jin dan setan, selain menggunakan Kitab Allah. Seorang Yahudi yang dikenal dalam sejarah suka bekerja sama dengan jin dan setan adalah Labīd b. al-A'șam yang pernah menyihir nabi tetapi gagal. ${ }^{26}$ Sedangkan praktik ruquah dengan menggunakan Kitab Allah pernah dilakukan oleh seorang wanita Yahudi saat melakukan ruqyah kepada 'A' 'ishah puteri Abū Bakr yang sedang sakit. Pada suatu ketika, Abū Bakr datang ke rumah 'A''ishah yang sedang menderita sakit, dan mendapati seorang wanita Yahudi yang akan mengobati 'A' ishah dengan cara ruqyah. Maka Abū Bakr memerintahkan kepada wanita Yahudi itu untuk melakukan ruqyah dengan Kitab Allah, yaitu dengan Taurat dan Injil. ${ }^{27}$ Peristiwa ini menunjukkan bahwa ruqyah, selain pernah dilakukan oleh orang-orang Arab jahiliyah, juga pernah dilakukan oleh orang-orang Arab Yahudi.

\footnotetext{
24 Ibn Hanbal, Musnad, Vol. 1, 381. Al-Arnowt berkomentar bahwa Hadìth ini saḅĭ li ghayrih.

25 Abū al-Husayn Muslim b. al-Hajjāj b. Muslim al-Qushayrī al-Naysābūrī, alJāmi' al-Ṣaḥ̂h, Vol. 4, ed. Muḥammad Fu'ād 'Abd al-Bāqī (Beirut: Dār al-Āfāq alJadīdah, t.th.), 1772.

${ }^{26}$ Abū 'Abd Allāh Muhammad b. Ismā'îl b. Ibrāhīm b. al-Mughīrah al-Bukhārī, Sahīḥ al-Bukhārì bi Hāshiyat al-Sindī, Vol. 4 (Beirut: Dār al-Fikr, t.th.), 20.

27 Jawwād 'Alī, Al-Mufașsal Fì Tärìkh al-'Arab Qabl al-Islām, Vol. 12 (t.t.: Dār alSāqī, 2001), 136.
} 
Berangkat dari peristiwa yang terjadi berdasarkan hadìth-ḥadìth tersebut, maka kata ruqyah tidak boleh dipahami dalam arti mantra sebagaimana dimaksudkan oleh mereka yang mempercayainya sebagai kalimat-kalimat yang dapat menghadirkan kekuatan magis. Ruqyah seharusnya diartikan sebagai salah satu sebab yang bisa menyembuhkan atas izin Allah; ia semata bukan penyembuh, melainkan hanyalah kalimat-kalimat yang diajarkan atau dibenarkan oleh nabi untuk diucapkan dalam upaya memohon kesembuhan dan keselamatan kepada Allah, yang pengaruhnya berpulang semata-mata kepada kehendak Allah.

Saat kedatangan Islam pun, kepercayaan yang demikian kuat di kalangan masyarakat pra-Islam terhadap ruqyah yang mengandung magis ini masih dipertahankan dengan tetap menggunakan istilah tersebut, tetapi makna semantiknya telah diubah sehingga sejalan dengan akidah Islam. Dengan demikian, kata ruqyah telah diislamkan oleh al-Qur'ān melalui pengajaran dan praktik nabi serta para sahabatnya, sehingga muncul kategori ruqyah yang dibenarkan dan ruqyah yang tidak dilarang.

Ibn Ḥajar al-'Asqalānī mengatakan: “...para ulama telah sepakat bahwa ruqyah yang dibolehkan adalah ruqyah yang memenuhi tiga syarat, yaitu (1) melakukan ruqyah dengan meng-gunakan ayat-ayat al-Qur'ān atau dengan menggunakan nama-nama dan sifat-sifatNya; (2) melakukan ruqyah dengan mengguna-kan bahasa Arab atau bahasa lain yang bisa dimengerti maknanya; dan (3) mempercayai sepenuhnya bahwa penyembuhan yang terjadi adalah semata-mata atas izin dan restu dari Allah. ${ }^{28}$

\section{Tenik Suwuk atau Ruqyah}

Mengenai teknik dan media yang digunakana dalam melakukan suwnk atau ruqyah, berdasarkan beberapa hadīth nabi dan athar sahabat, dapat diketahui bagaimana cara-cara melakukannya dan media apa yang dipergunakan, yaitu di antaranya: Pertama, sekadar membacakan doa atau membacakan beberapa ayat al-Qur'ān. Hadīth riwayat Aḥmad dan lain-lain dari Abū Sa īd al-Khudrī menegaskan: "Sesungguhnya Jibril pernah mendatangi nabi kemudian berkata: 'Apakah engkau sedang sakit wahai Muhammad?'. Nabi menjawab: 'Ya'. Lalu Jibril membacakan bism Allāh

\footnotetext{
28 Ibn Ḥajar al-'Asqalānī, Fatḥ al-Bārū Sharh Ṣaḥ̣̣̄ al-Bukhārì, Vol. 10 (Beirut: Dār al-Ma'rifah, t.th.), 166.
} 
arqik min kull shay' yu'dhik min sharr kull nafs wa 'ayn yashfik bi ism Alläh arqik" (dengan nama Allah aku me-ruquah-mu dari segala sesuatu yang membuatmu sakit, dan dari kejahatan semua jiwa serta pandangan mata. Allahlah yang akan menyembuhkanmu, dengan nama Allah aku me-ruquah-mu). ${ }^{29}$ Hadìth tersebut menjelaskan tentang Jibril yang melakukan ruqvah setelah mengetahui nabi sedang menderita sakit. Dalam melakukan ruqyah, Jibril membacakan doa dengan menggunakan asmä' Allah.

Kedua, membaca doa, kemudian meniup kedua telapak tangan dan mengusapnya ke seluruh anggota badan. Hadìth riwayat alBukhārī dan Muslim dari 'Á'ishah menerangkan bahwasanya Rasulullah, apabila sedang sakit, meniup tangannya untuk dirinya sendiri dengan membaca surat al-Mu'awwidhät lalu mengusap dengan tangannya sendiri. Ketika sakitnya semakin parah, saat menjelang wafatnya, maka ' $\overline{\mathrm{A}}$ 'ishah yang meniupkan untuk dirinya dengan tangan beliau sambil membaca surat al-Mu'awwidhāt sebagaimana dulu nabi meniup untuk dirinya dan mengusap dengan tangannya. ${ }^{30}$ Hadīth ini menerangkan bahwa ketika nabi sakit, ia melakukan ruqyah untuk dirinya sendiri dengan cara meniup sendiri, membaca surat al-Mu'awwidhät dan mengusapkan dengan tangannya sendiri. Al-Mubārakfūrîn ${ }^{-31}$ dalam kitab Mir'ät alMafätīh Sharh Mishkāt al-Masäbīh, menjelaskan bahwa yang dimaksud dengan meniup adalah mengeluarkan angin dari mulut tanpa mengeluarkan air ludah. Sedangkan yang dimaksudkan dengan istilah al-Mu'awwidhāt adalah surat al-Ikhlāṣ, al-Falaq dan alNās (surat-surat untuk mohon perlindungan), atau bisa juga ayatayat lain yang mengandung permohonan perlindungan, seperti ayat 97 dan 98 surat al-Mu'minūn. Adapun yang dimaksud dengan mengusap pakai tangan adalah mengusap dengan tangannya ke anggota badannya. Mengenai perbuatan 'Ā'ishah yang melakukan ruqyah kepada nabi (saat beliau sakit parah) dengan menggunakan

\footnotetext{
${ }^{29}$ Ibn Hanbal, Musnad, Vol. 3, 56. Al-Albānī menilai sahīḥ hadīth ini. Lihat alAlbānī, Șahīh al-Jāmi‘ al-Saghìr wa Ziyādatuh, Vol. 1 (Beirut: al-Maktab al-Islāmī, 1988), 7.

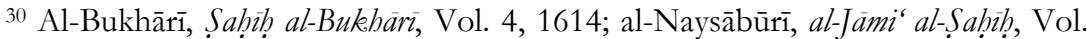
7,16 .

31 Abū al-Ḥasan 'Ubayd Allāh b. Muḥammad 'Abd al-Salām al-Mubārakfūrī,

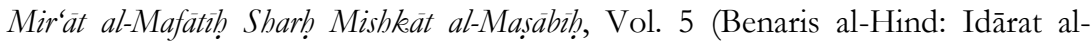
Buhūth al-'Ilmīyah wa al-Da'wah wa al-Iftā’, 1984), 222.
} 
tangan nabi itu adalah karena tangan beliau diyakini lebih banyak keberkahannya.

Ketiga, membaca doa, meniup dan sedikit meludah. Dalam hadīith riwayat al-Bukhārī dari Abū Sa ${ }^{\top} \overline{1} d$ al-Khudrī diceritakan bahwasanya ada sekelompok sahabat nabi yang sedang menempuh perjalanan. Di tengah-tengah perjalanan, para sahabat itu singgah di sebuah kampung Arab. Mereka berharap agar penduduk kampung berkenan memberikan jamuan sebagai tamu. Namun, tak ada satu pun dari penduduk kampung yang mau menjamunya. Tidak lama kemudian datang berita yang menerangkan bahwa pemimpin kampung itu terkena sengatan. Mengetahui pemimpinnya butuh bantuan penyembuhan, maka penduduk kampung berusaha mencari penawarnya. Tetapi usaha mereka itu tidak berhasil, lalu salah seorang di antara penduduk kampung itu bermusyawarah dengan teman-temannya untuk menemui sekelompok sahabat nabi yang sedang singgah, barangkali ada di antara mereka yang memiliki pengalaman menyembuhkan sakit akibat sengatan hewan berbisa. Perwakilan dari penduduk kampung itu akhirnya menemui sekelompok sahabat nabi dan berkata: "Wahai saudara-saudara sekalian, pemimpin kami telah tersengat hewan berbisa, kami sudah mengupayakan berbagai cara untuk memperoleh penyembuhannya, tetapi gagal. Apakah di antara kalian ada yang memiliki sesuatu (pengalaman untuk mengobatinya)?".

Mendengar keterangan penduduk kampung itu, ada di antara sahabat nabi yang menjawab: "Ya, demi Allah saya adalah seorang rāqi (ahli melakukan ruqyah). Namun, demi Allah kami telah meminta jamuan kepada kalian tetapi tidak ada di antara kalian yang menjamu kami, karena itu saya tidak akan melakukan ruqyah (pengobatan) kepada kalian kecuali jika kalian memberikan upah kepada kami". Mendengar pernyataan sahabat nabi itu, maka penduduk kampung itu setuju untuk memberi upah beberapa ekor kambing. Setelah terjadi kesepakatan, seorang sahabat nabi kemudian mendatangi pemimpin kampung yang tengah sakit itu lalu melakukan ruqyah dengan cara meniup dengan sedikit meludah sambil membaca al-hamd li Alläh rabb al-älamin (surat al-Fātihah). Setelah itu, tidak lama kemudian pemimpin kampung itu merasa lega, terbebas dari ikatan dan selanjutnya dapat berjalan dengan baik tanpa ada gangguan sama sekali. Sebagai hadiahnya, penduduk 
kampung menyerahkan upah sesuai yang telah disepakati. Beberapa sahabat berkata: "Bagilah". Seorang sahabat yang tadi melakukan ruqyah berkata: "Jangan dibagi dulu sebelum kita menghadap kepada Rasulullah dan menceritakan kepadanya tentang peristiwa yang telah terjadi pada kita, dan apa yang akan diperintahkan kepada kita". Para sahabat pun akhirnya mendatangi Rasulullah dan menceritakan apa saja yang telah mereka alami. Menyimak apa yang telah terjadi pada para sahabat itu, nabi bersabda: "Kalian tahu dari mana kalau al-Fātiḥah itu bisa digunakan untuk me-ruqyah? Kalian benar, maka bagikanlah upahnya dan berikan juga bagiannya untukku". ${ }^{32}$

Keempat, membaca doa dan meletakkan tangan kanan ke bagian badan yang terasa sakit serta mengusapnya. 'Uthmān b. Abī al-'Āṣ al-Thaqafi menceritakan bahwa ia pernah mengadu kepada Rasulullah perihal rasa sakit yang dirasakan di badannya semenjak ia masuk Islam. Maka Rasulullah bersabda: "Letakkan tanganmu di atas bagian tubuhmu yang terasa sakit, kemudian ucapkanlah basmalah sebanyak tiga kali lalu ucapkan $a^{\prime} \bar{u} d h-u$ bi Alläh wa qudratih min sharr mā ajid wa uhädhir" (aku berlindung kepada Allah dan kekuasaan-Nya dari kejahatan atau keburukan yang aku temui dan yang aku takuti) sebanyak tujuh kali. ${ }^{33}$

Kelima, membaca doa dan meletakkan jari di tanah kemudian mengangkatnya. 'Á'ishah menceritakan bahwa apabila ada seseorang yang mengeluh kepada Rasulullah tentang rasa sakit akibat bisul (bernanah) atau luka, maka Rasulullah membacakan doa sambil meletakkan jarinya di atas tanah, sebagaimana Sufyān b. 'Uyaynah mencontohkan dengan meletakkan jari telunjuknya di atas tanah kemudian mengangkatnya dan berdoa bi ism Alläh turbat ardinā bi rīqat ba'dinā li yushfä bih saqimunā bi 'idhn rabbinā (dengan nama Allah, tanah bumi kita ini, dengan ludah sebagian kami, semoga dengannya disembuhkan sakit kami dengan izin Tuhan kami). ${ }^{34}$

Keenam, membaca doa dan memasukkan tangan ke dalam air yang dicampur dengan garam. Diceritakan, pada suatu waktu, nabi

\footnotetext{
32 Al-Bukhārī, al-Jāmi‘ al-Ṣahīh, Vol. 5, 2169. Selain oleh al-Bukhārī, hadīth ini juga diriwayatkan dalam Ibn Hanbal, Musnad, Vol. 5, 51.

33 Al-Naysābūrī, Sahīh Muslim, Vol. 7, 20.

${ }^{34}$ Al-Bukhārī, Ṣahịh al-Bukhārī, Vol. 5, 2168. Al-Naysābūrī, Șaḥị̣ Muslim, Vol. 7, 17.
} 
sedang melaksanakan salat malam, tiba-tiba tangannya disengat oleh kalajengking. Setelah itu nabi mengambil air yang dicampur dengan garam kemudian dituangkan ke tangan yang terkena sengatan tadi, lalu dibacakan surat al-Kāfirūn, al-Ikhlāṣ, al-Falaq, dan al-Nās. Peristiwa ini termaktub dalam beberapa hadīth, salah satu di antaranya yaitu berbunyi:

'Alī b. Abī Ṭālib berkata: "Ketika Rasulullah sedang melakukan salat, beliau disengat kalajengking. Setelah selesai salat, beliau bersabda 'Semoga Allah melaknat kalajengking yang tidak membiarkan orang yang sedang dalam keadaan salat atau yang lainnya.' Lalu beliau mengambil sewadah air yang dicampur dengan garam. Kemudian beliau mengusap bagian anggota badannya yang telah disengat kalajengking, seraya membaca surat al-Kāfirūn, al-Falaq, dan al-Nās". ${ }^{35}$

Ketujuh, membaca doa, menuangkan Air Zamzam dan meminumnya. Diriwayatkan bahwa 'A' 'ishah pernah membawa Air Zamzam sebagaimana Rasulullah juga pernah membawanya di dalam kantong kulit dan geriba, kemudian beliau menuangkannya pada orang yang sakit dan meminumkannya. ${ }^{36}$ Hadīth tentang masalah ini juga diriwayatkan oleh al-Bukhārī dalam al-Tärikkh alKabir Vol. 2/173, al-Tirmidhī Vol. 1/180, dan al-Bayhaqī Vol. $5 / 202 .{ }^{37}$ Hadīth tersebut menerangkan bahwa salah satu cara meruqyah yang dicontohkan oleh Rasulullah adalah dengan membawakan Air Zamzam untuk dituangkan pada orang yang sedang sakit atau diminumkannya.

Kedelapan, menulis beberapa ayat al-Qur'ān atau doa-doa pada kertas atau alat-alat yang tidak rusak terkena air, kemudian diminumkan atau digunakan untuk mandi. Sa'īd b. Jubayr mendapatkan keterangan dari 'Abd Allāh b. 'Abbās tentang wanita yang mengalami kesulitan saat hendak melahirkan. Ia mengatakan bahwa ayat al-Qur'an atau doa-doa tersebut hendaknya dituliskan di atas kertas, dimasukkan dalam bejana berisi air, kemudian diminumkan. Ayat atau doa-doa yang dimaksud adalah: bi ism Allāh

\footnotetext{
35 Sulaymān b. Aḥmad b. Ayyūb Abū al-Qāsim al-Ṭabrānī, al-Mu'jam al-Saghìr, Vol. 2 (Beirut: al-Maktab al-Islāmī, 1985), 87. Al-Albānī mensahihkannya, dalam al-Albānī, al-Silsilah al-Aḥädìth al-Saḥ̣̄hah, Vol. 2 (Riyadh: Maktabat al-Ma‘ārif, t.th.), 89.

${ }^{36}$ Aḥmad b. al-Ḥusayn b. 'Alī b. Mūsā Abū Bakr al-Bayhaqī. Sunan al-Bayhaqì alKubrā, Vol. 2 (Mekah al-Mukarramah: Maktabat Dār al-Bāz, 1994), 401.

${ }^{37}$ Al-Albānī, al-Silsilah al-Aḥädìth, Vol. 2, 543.
} 
alladhì là iläh illà huwa al-ḥakim al-karìm, subhän-a Allāh wa ta'älà rabb al-'arsh al-'ażim, al-ḩamd li Alläh rabb al-älamin; kemudian surat alAḥāf [46]: 35, “...ka'annabum yawm yarawna mà yū'adūn lam yalbatbū illà sā'at min nahär balägh fa hal yublake illā al-qawm al-fäsiqün, artinya: pada hari mereka melihat azab yang diancamkan kepada mereka, (merasa) seolah-olah tidak tinggal (di dunia) melainkan sesaat pada siang hari, (inilah) suatu pelajaran yang cukup, maka tidak dibinasakan melainkan kaum yang fasik; dan surat al-Nāzi'āt [79]: 46, ka'annabum yawm yarawnahà lam yalbathù 'illà 'ashiyyah aw duhāhāa, artinya: "pada hari mereka melihat hari kebangkitan itu, mereka merasa seakan-akan tidak tinggal (di dunia) melainkan (sebentar saja) di waktu sore atau pagi hari. Hadīth tentang ini mawqüf pada Ibn 'Abbās. ${ }^{38}$ 'Abd Allāh b. Aḥmad berkata: "Aku melihat ayahku (Imām Aḥmad) menulis doa dan ayat-ayat tersebut pada tempat minuman yang putih atau sesuatu yang bersih untuk seorang wanita yang sedang mengalami kesulitan saat hendak melahirkan". ${ }^{39}$ Menurut Ibn al-Qayyim, menulis bacaan atau doadoa (pada bejana yang berisi air) untuk ruquah itu bisa memberikan manfaat. Lebih lanjut, Ibn al-Qayyim mengatakan bahwa beberapa ulama salaf telah memberikan rukhsah (keringanan) tentang bolehnya menulis beberapa ayat al-Qur'ān pada sebuah gelas berisi air atau tempat minuman yang bersih lalu meminumnya. Hal itu bisa menjadi sarana untuk pengobatan atau penyembuhan. ${ }^{40}$

Kesembilan, memukul dada, kemudian meniup mulut dengan sedikit air ludah dan mengusap wajah dengan air sambil membaca doa. Seperti dalam hadīth riwayat Ibn Mājah dari 'Uthmān b. Abī al-'Āṣ, diceritakan bahwa 'Uthmān b. Abī al-'Āṣ mengatakan bahwa ketika ia bekerja untuk Rasulullah di Ṭā'if, tiba-tiba ia melihat sesuatu dalam salatnya, sampai-sampai ia tidak mengetahui sedang salat apa. Setelah kejadian itu, ia kemudian menemui Rasulullah. Beliau berkata, "Ibn Abī al-'Ạṣ?" Ia pun menjawab, "benar, ya Rasulullah.” Rasul bertanya, "apa yang mendorongmu

\footnotetext{
${ }^{38}$ Al-Bayhaqī, Kitāb al-Da'awāt al-Kabìr, Vol. 2 (t.t.: t.tp., t.th.), 282.

39 Muhammad al-Ṣāyim, Murshid al-Mu'älijìn bi al-Qur'ān al-Karim (Kairo: Dār alFadīlah, 2006), 22; Abū al-Ṭìb, 'Awn al-Ma'būd, Vol. 8, 186.

40 Muḥammad b. Abī Bakr b. Ayyūb b. Sa'd Shams al-Dīn b. al-Qayyim alJawzìyah, Zäd al-Ma'àd fì Hady Khayr al-Ibād, Vol. 4 (Beirut: Mu'assasat alRisālah, 1994 M dan 1986), 326.
} 
datang ke sini?" Ia menjawab, "wahai Rasulullah, aku melihat sesuatu dalam salatku sampai-sampai aku tidak tahu aku sedang salat apa". Nabi menjawab, "itu adalah perbuatan setan, mendekatlah kepadaku!" Ia pun mendekat kepada nabi, dan duduk di atas kedua telapak kakinya. Lebih lanjut Ibn Abī al-'Āṣ menceritakan, bahwa dengan tanggaya nabi kemudian memukul dada dan meniup mulut Ibn Abī al-'Āṣ sambil berkata, "keluarlah wahai musuh Allah!” Nabi melakukannya sebanyak tiga kali. Lalu nabi berkata, "teruskanlah pekerjaanmu". ${ }^{41}$

Riwayat, yang tak lain adalah hadīth, di atas menjelaskan tentang cara nabi melakukan ruqyah terhadap seorang sahabat yang bernama Ibn Abī al-'Āṣ yang terganggu oleh setan saat melakukan salatnya. Pada waktu itu nabi melakukan ruqyah kepadanya dengan cara memukul dada kemudian meniup mulutnya sambil mengucapkan: “ukhruj 'aduwwalläh?' (keluarlah wahai musuh Allah). Cara ruqyah ini dilakukan oleh nabi sebanyak tiga kali. Mengenai bacaan-bacaan doanya, Sa'īd b. 'Alī b. Wahf al-Qaḥtānī mengatakan bahwa bacaan ruqyah atau sunve yang paling agung adalah surat al-Fātihah, ayat al-Kursī, dua ayat terakhir dari surat al-Baqarah, alIkhlāṣ, al-Falaq, dan al-Nās sambil meniupkan kepada orang yang terkena penyakit gila. Selain bacaan tersebut boleh juga dengan bacaan-bacaan ayat lain yang terdapat dalam al-Qur'ān, karena sesungguhnya seluruh al-Qur'ān itu merupakan obat atau penyembuh apa yang ada dalam dada dan menjadi petunjuk serta rahmat bagi orang-orang yang beriman. ${ }^{42}$

\section{Tinjauan Sains ${ }^{43}$ Modern tentang Suwuk atau Ruqyah}

Secara umum, sumuk dan ruqyah itu hampir tidak bisa dibedakan. Keduanya merupakan upaya alternatif untuk mendapatkan kebebasan atau kesembuhan dari segala macam gangguan, baik

\footnotetext{
41 Al-Qazwīnī, Sunan Ibn Mājah, Vol. 11 (t.t.: t.tp., t.th.), 32. Al-Albānī menilai bahwa hạāith ini sahih. Al-Albānī, al-Silsilah al-Aḥ̄àith, Vol. 6, 417.

${ }^{42}$ Sa'īd b. 'Alī b. Wahf al-Qahțān̄i, al-Du'ā' min al-Kitāb wa al-Sunnah wa Yalīh alTlāj bi al-Ruqā min al-Kitāb wa al-Sunnah (Riyadh: al-Mațābi‘ al-Ḥamiḍī, 1422), 113.

${ }^{43}$ Sains (scientia, science) dalam pengertian sebenarnya adalah ilmu pengetahuan yang mempelajari berbagai fenomena alam sehingga rahasia yang dikandungnya dapat diungkap dan dipahami. Dalam usaha mengungkap rahasia alam tersebut, sains melakukannya dengan menggunakan metode ilmiah. Dalam hal ini meliputi langkah-langkah sistematis, bersifat objektif, logis, dan bersifat universal. Lihat http://www.pengertianahli.com/ 2013/12.
} 
gangguan fisik maupun non-fisik. Dalam praktiknya, baik sumuk maupun ruqyah biasanya menggunakan media air. Selain itu, yang biasa melakukan sumnk atau ruqyah itu adalah orang yang sudah tua atau yang dipandang tua karena keahliannya di bidang penyembuhan. Sementara yang membedakannya hanyalah asal kawasan di mana istilah itu muncul. Jika sumuk berasal dari Jawa, maka ruqyah berasal dari Arab.

Di Jawa, terutama di kalangan Muslim yang saleh atau kaum santri dalam istilah Geertz, kegiatan suwuk sebenarnya adalah kegiatan ruqyah itu sendiri. Oleh karena itu, mantra, jampi atau bacaan yang digunakan dalam menyuwuk atau me-ruqyah adalah bacaan yang ma'thūr, yaitu dari al-Qur'ān dan doa-doa dari nabi. Jika dulu para ulama Jawa (termasuk Walisongo) tidak memopulerkan istilah ruquah, hal itu tak lain demi mempermudah penerimaan atau pemahaman dari masyarakat Jawa yang sebelumnya didominasi oleh keyakinan Hindu-Buddha dan Animisme-Dinamisme, yang sudah akrab dengan istilah suwuk. Namun demikian, suwuk yang dimaksud memiliki muatan yang sama dengan ruqyah ilähiyah atau ruqyah sharìyah, yang sesuai dengan al-Qur'ān dan Sunnah Nabi. Kini, istilah ruqyah sudah mulai populer di masyarakat Jawa, bahkan di kalangan kaum Muslim tertentu lebih populer dari pada suwnk, karena banyaknya pusat-pusat kajian yang berbasis kitabkitab dari Timur Tengah yang berbahasa Arab.

Tinjauan sains modern terhadap sumuk atau ruqyah setidaknya dapat dilihat dari dua aspek, yaitu aspek penggunaan media dan aspek pihak terapis yang dipercaya atau kredibel. Dalam praktik sumuk atau ruqyah, air menjadi media yang sangat penting. Air yang sudah di-sumuk atau di-ruqyah dapat diminumkan kepada pasien atau dipercikkan ke tubuh pasien, bahkan bisa digunakan untuk mandi. Zaman dahulu, di kalangan Muslim puritan atau Muslim modern, hal ini dianggap sebagai sesuatu yang mengandung syirik. Namun kini, setelah Masaru Emoto dari Universitas Yokohama Jepang mempublikasikan hasil temuannya tentang keajaiban air, banyak kalangan yang tidak lagi menganggapnya syirik, karena mulai memahami betapa dahsyatnya "kekuatan" air, sehingga wajar jika dalam pengobatan sumuk atau ruqyah sering mengandalkan media air.

Pada awal tahun 2000an, Emoto melakukan penelitian tentang eksistensi air dan perilakunya. Dalam hipotesisnya, Emoto 
mengatakan bahwa air dapat menyusun kristal dalam bentuk yang berbeda-beda, dan hal ini bergantung kepada informasi yang diterimanya. Ia yakin bahwa perbedaan bentuk kristal es bukan hanya karena ada tidaknya klorin, ${ }^{44}$ melainkan karena ada informasiinformasi lain yang mempengaruhinya. Untuk menguji hal ini, Emoto memasukkan air ke dalam dua gelas. Gelas pertama diberi label tulisan "terima kasih", sedangkan botol lainnya diberi label tulisan "kamu bodoh". Air yang dimasukkan ke dalam dua botol tersebut kemudian dibekukan melalui freezer (dengan suhu $-25^{\circ} \mathrm{C} /-$ $13^{\circ} \mathrm{F}$. Hasilnya, di luar dugaan Emoto, air dengan label tulisan "terima kasih" membentuk kristal heksagonal yang sangat indah, sedangkan air dengan label tulisan "kamu bodoh" hanya membentuk pecahan-pecahan kristal. Hasil eksperimen tersebut dapat disimpulkan bahwa kualitas air dapat berubah tergantung informasi yang diperolehnya. ${ }^{45}$

Lebih lanjut, Emoto melakukan eksperimen terhadap 500 orang untuk berkonsentrasi memusatkan pesan "peace" di depan sebotol air. Hasilnya, kristal air tadi kemudian mengembang bercabang-cabang dengan indahnya. Ketika sebotol air itu coba dibacakan doa Islam, kristal bersegi enam dengan lima cabang daun muncul berkilauan. Emoto akhirnya berkeliling ke berbagai belahan dunia untuk melakukan percobaan dengan air di Swiss, Berlin, Prancis, Palestina, bahkan ia kemudian diundang ke Markas Besar PBB di New York untuk mempresentasikan hasil temuannya pada bulan Maret 2005 lalu. Emoto membuktikan bahwa air ternyata bisa "mendengar" kata-kata, bisa "membaca" tulisan, dan bisa "mengerti" pesan. Emoto dalam bukunya yang lain, Message From Water, menguraikan bahwa air bisa merekam pesan, seperti pita magnetik atau Compact Disk (CD). Semakin kuat konsentrasi

\footnotetext{
${ }^{44}$ Klorin adalah unsur halogen yang paling banyak terdapat di alam namun jarang ditemui dalam bentuk bebas. Pada umumnya klorin ditemukan dalam bentuk garam halida dan ion klorida (Lihat: sifat-sifat unsur Halogen). Sumber utama klorin adalah air laut. Dalam air laut klorin berbentuk ion klorida. Pada proses pembuatan garam, ion klorida akan berikatan dengan unsur Natrium membentuk garam Natrium klorida atau garam dapur. http://www.kamusq.com/2012/11/klorin-adalah-pengertian-dan-definisi.html. 45 Masaru Emoto, The True Power Of Water: Hikmah Air dalam Olab Jiwa, terj. Azam Translator (Bandung: MQ Publishing, 2006), 13.
} 
dari pemberi pesan, maka semakin dalam pesan tercetak di dalam air. Air bisa mentransfer pesan melalui molekul air yang lain. ${ }^{46}$

Lebih lanjut, Emoto mengatakan bahwa air itu bersifat sensitif. Ia akan merespons setiap kata yang diucapkan manusia. Apabila manusia mengirimkan hado (efek gelombang energi) yang baik kepada air dengan mengatakan kata-kata positif, maka air akan mempersembahkan kristal-kristal yang indah. Demikian pula doa dapat mengeluarkan energi yang dapat mengubah kualitas air. Memberikan doa kepada air berarti mengirimkan bado ke dalam air, dan air kemudian menggunakan kekuatan atau energinya untuk menjawab apa yang terkandung dalam suatu doa. Menurut Emoto, doa-doa yang biasa digunakan dalam ajaran agama memiliki energi hado yang sangat kuat. Jika seseorang menjalani agama dengan baik dan berdoa dengan khusyuk tanpa keraguan, ia akan mendapatkan keberkahan dan kekuatan yang sangat dahsyat. ${ }^{47}$

Siti Fadilah Supari, seorang akademisi yang juga dokter spesialis jantung yang pernah menjabat Menteri Kesehatan Republik Indonesia (2004-2009), menyatakan bahwa Emoto, melalui riset ilmiahnya selama bertahun-tahun, telah berhasil menjadikan air sebagai sarana pengobatan atau penyembuhan alternatif terhadap berbagai gangguan kesehatan. Hal ini, menurut Supari, semakin menguatkan arti penting menjembantani pengobatan kedokteran modern dengan pengobatan alternatif. ${ }^{48}$

Berdasarkan hasil temuan Emoto tersebut, dapat dipahami bahwa air putih yang didoakan atau di-sumuk oleh terapis bisa memberikan efek kesembuhan pada orang sakit. Molekul air ternyata bisa menangkap pesan doa kesembuhan, menyimpannya, lalu vibrasinya merambat kepada molekul air lain yang ada di tubuh orang yang sakit. Selanjutnya, doa atau suwnk tersebut memformat efek energi air ( $h a d o$ ) sehingga bisa berfungsi menyembuhkan berbagai penyakit.

Selain media air yang dipandang penting dalam proses sumuk atau ruqyah, faktor terapis dari penyuwuk atau pe-ruqyah juga sangat menentukan dalam memberikan efek kesembuhan. Dalam hal ini,

\footnotetext{
46 Masaru Emoto, Message From Water, Vol. 2 (t.t.: Hado Kyoiku Sha Co., Ltd, 2001).

${ }^{47}$ Emoto, The True Power, 113-115.

48 Siti Fadilah Supari dalam komentarnya terhadap buku Emoto, The True Power of Water.
} 
peran penyuwuk atau pe-ruqyah dari kalangan orang terpandang, terhormat, dan diyakini sebagai orang yang mumpuni, akan memberikan sugesti tersendiri bagi pasien untuk lebih memberikan harapan dan keyakinan dalam memperoleh kesembuhan.

Panati Charles (1989), seorang ahli kesehatan modern, melaporkan hasil penelitiannya tentang hubungan pikiran, keyakinan, dan kepasrahan dengan kesembuhan. Penelitian ini dilakukan kepada sejumlah pasien di rumah sakit jiwa dengan membaginya menjadi dua kelompok. Kelompok pertama, pasien menerima obat penenang stolazine, sementara kelompok lainya, pasien diberi placebo, yaitu obat tanpa isi atau obat palsu sekadar untuk memberi sugesti. Percobaan tersebut dilaksanakan dengan cara sedemikian rupa sehingga dokter dan pasien pun tidak mengetahuai siapa yang menerima obat sungguhan dan siapa yang menerima obat plazebo. Penelitian ini hasilnya sangat mengejutkan karena pasien yang mengkonsumsi obat placebo yang menjadi lebih tenang ternyata jumlahnya sedikit lebih banyak dibandingkan dengan pasien yang telah diberi obat stolazine. Percobaan terhadap dua kelompok ini kemudian diulangi lagi untuk mendapatkan bukti yang lebih meyakinkan. Pada percobaan yang kedua ini para pasien diberi takaran dua kali lipat dan diberi tahu (diyakinkan, disugesti) bahwa takaran tambahan tersebut akan mempercepat reaksi mereka terhadap penyembuhan. Hasilnya ternyata lebih mengejutkan lagi; mereka yang mendapat takaran placebo menjadi lebih rileks dua kali lipat dibandingkan dengan mereka yang menerima dua kali takaran obat yang sebenarnya. ${ }^{49}$

Penelitian dan eksperimen yang dilakukan oleh Panati tersebut menunjukkan bahwa faktor pikiran, keyakinan, dan sugesti bisa menjadi sangat berpengaruh terhadap penyembuhan. Ketika seorang terapis berhasil meyakinkan pasien dengan nasihat-nasihat dan doa-doanya, maka pasien akan merasa lebih tenang. Jika dikaitkan dengan teori penyembuhan melalui pineal therapy, ${ }^{50}$ maka

49 Moh. Sholeh, Bertobat sambil Berobat: Rahasia Ibadab untuk. Mencegab dan Menyembubkan Berbagai Penyakit (Bandung: Hikmah, 2008), 154.

50 Yang dimaksud dengan terapi pineal adalah terapi yang memfokuskan pada kelenjar otak yang bernama pineal atau pineal gland. Dalam hal ini, terapi yang dilakukan adalah dengan menjaga dan mengkondisikan agar kelenjar pineal dapat memproduksi hormon sesuai yang dibutuhkan oleh tubuh manusia. Kelenjar pineal ini dipandang mampu menaklukkan berbagai penyakit yang datang 
sesungguhnya suasana hati yang tenang dan tenteramlah yang bisa membantu kelenjar pineal dalam memproduksi hormon melatonin. ${ }^{51}$ Ketika hormon melatonin berhasil diproduksi dalam jumlah yang memadai dalam tubuh seorang pasien, maka akan dapat digunakan untuk mencegah dan menyembuhkan berbagai penyakit.

\section{Penutup}

Sumuk secara esensial sama dengan ruqyah. Sumuk berasal dari bahasa Jawa sedangkan ruqyah berasal dari bahasa Arab. Keduanya bermakna sama, yaitu cara penyembuhan atau pembebasan dari segala penyakit atau sesuatu yang mengganggu manusia, dengan cara membacakan sesuatu di dekat orang yang sakit atau di dekat orang yang sedang mengalami gangguan. Selain dengan membacakan sesuatu terkadang disertai dengan media air untuk diusapkan atau dipercikkan ke tubuh orang yang sakit, atau diminumkan, bahkan bisa juga digunakan untuk mandi dengan maksud mendapatkan berkahnya.

Sumuk atau ruqyah adalah metode penyembuhan alternatif yg bersifat umum. Bila penggunanya orang yang tidak bertauhid, maka bisa disalahgunakan dengan melibatkan kekuatan lain seperti jin. Namun, bila yang menggunakannya merupakan orang yang bertauhid, maka akan aman dan bebas dari bahaya syirik, sebab orang yang bertauhid akan berusaha merujuk kepada ajaran nabi dalam melakukan sunve atau ruqyah dan hanya berharap penyembuhan kepada Allah. Sunvk belakangan ini semakin bisa diterima oleh masyarakat luas, karena mendapatkan legalisasi dari al-Qur'ān dan Hadith berdasarkan keterangan dari sejumlah kitab yang berbahasa Arab, dan diperkuat oleh temuan sains modern tentangnya.

Dalam tinjauan sains modern, penyembuhan dengan sumuk atau ruqyah dapat dilihat dari dua sisi. Pertama, dari sisi media yang digunakan, yaitu air. Hasil temuan atau eksperimen Masaru Emoto

menyerang. Iftachul 'Ain Hambali, Islamic Pineal Theraphy (Jakarta: Prestasi, 2011), 9.

51 Hormon melatonin sangat berperan dalam mengatur, mengontrol, dan mengendalikan kelenjar dan hormon yang lain serta fungsi-fungsi biologis organ tubuh yang lain, di antaranya 1) mengurangi ketegangan jiwa; 2) memperbaiki tidur; 3) memperkuat daya kekebalan tubuh; meningkatkan daya tahan terhadap bakteri dan virus; 4) mencegah kanker; dan 5) mencegah pikun. Hambali, Islamic Pineal Therapy, 22-23. 
menunjukkan bahwa air ternyata bisa mendengar, membaca, dan mentransfer ke arah yang dituju. Jika seorang terapis membacakan sesuatu untuk kesembuhan melalui air, maka pesan itu akan diteruskan oleh air menjadi energi positif yang bisa memberikan efek kesembuhan. Kedua, dari sisi terapis, bila orang yang melakukan terapi diyakini oleh si pasien sebagai seorang yang mumpuni, ahli, dan berpengalaman, maka si pasien akan merasa tenang. Kondisi pasien yang tenang dan bahagia inilah yang akan menumbuhkan hormon melatonin dalam tubuhnya, yang nantinya bisa berpengaruh pada penetralan dari energi-energi negatif sehingga pasien bisa terbebas dari sakitnya.

\section{Daftar Rujukan}

Albānī (al), Muḥammad Nāṣir al-Dīn. al-Silsilah al-Aḥāìith alSahīhah, Vol. 2 dan 6. Riyadh: Maktabat al-Ma'ārif, t.th.

----. Da if Sunan al-Tirmidhi, Vol. 1. t.t.: t.tp., t.th.

----. Sabīh al-Jämi al-Saghì wa Ziyädatuh, Vol. 1. Beirut: al-Maktab al-Istāmī, 1988.

Alī, Jawwād. al-Mufașsal fì Tärìkh al-'Arab Qabl al-Islām, Vol. 12. t.t.: Dār al-Sāqīi, 2001.

Anis, Ibrāhīm et al. al-Mu'jam al-W asit, Vol. 2. t.t.: Dār al-Fikr, t.th. Anwar, Rosihan. Demi Dakwah. Bandung: Al Ma'arif, 1976.

Asqalānī (al), Aḥmad b. 'Alī b. Hajar Abū al-Faḍl. Fatḥ al-Bārì Sharh Saḥ̄h al-Bukhārì, Vol. 10. Beirut: Dār al-Ma'rifah, 1379 H.

Bayhaqī (al), Aḥmad b. al-Ḥusayn b. 'Alī b. Mūsā Abū Bakr. Kitāb al-Da'awät al-Kabir, Vol. 2. t.t.: t.tp., t.th.

----. Sunan al-Bayhaqi al-Kubrā, Vol. 9. Mekah al-Mukarramah: Maktabat Dār al-Bāz, 1994.

Bukhārī (al), Abū 'Abd Allāh Muhammad b. Ismā'îl b. Ibrāhīm b. al-Mughīrah. Sahīì al-Bukhārì bi Hāshiyat al-Sindī, Vol. 4. Beirut: Dār al-Fikr, t.th.

Echols, John M. dan Hassan Shadily. Kamus Inggris Indonesia. Jakarta: PT. Gramedia, 1989.

Emoto, Masaru. The True Power of Water, Hikmah Air dalam Olah Jiwa, terj. Azam Translator. Bandung: MQ Publishing, 2006.

----. Message From Water, Vol. 2. t.t.: Hado Kyoiku Sha Co., Ltd, 2001.

Hambali, Iftachul 'Ain. Islamic Pineal Theraphy. Jakarta: Prestasi, 2011. 
http://jv.wiktionary.org/wiki/suwuk.

http://www.pengertianahli.com/ 2013/12.

Huda, Muhammad. "Kitab Risalat Khulq al-Kiram Wa Shifa alAjsam karya KH. Moh Sholeh". Tesis--UIN Sunan Ampel Surabaya, 2019.

Ibn al-Athīr. al-Nihāyat fì Gharīb al-Athar, Vol. 2. Beirut: alMaktabat al-'Ilmìyah, 1979.

Ibn 'Āshūr, Muhạammad al-Ṭāhir. al-Taḥ̂rì wa al-Tanwìr, Vol. 29. Tunis: al-Dār al-Tūnisīyah, 1984.

Ibn Hanbal, Aḥmad. Musnad al-Imām Aḥmad b. Hanbal, Vol. 1, 3, 5, dan 6, ed. Shu'ayb al-Arnowt et al. Kairo: Mu'assasah Qurțūbah, t.th.

Ibn Manẓūr, Muḥammad b. Mukrim. Lisān al-'Arab, Vol. 14. Beirut: Dār Șādr, t.th.

Ibn Taymìyah. Majmū' al-Fatāwà, Vol. 27. t.t.: Dār al-Wafā, 2005.

Jawzìyah (al), Muhammad b. Abī Bakr b. Ayyūb b. Sa'd Shams al-

Dīn Qayyim. al-Tỉbyān fì Aqsām al-Qur'àn, Vol. 1. Beirut: Dār alFikr, t.th.

----. Zād al-Ma'äd fì Hady Khayr al-Tbād, Vol. 4. Beirut: Mu'assasat al-Risālah, $1994 \mathrm{M}$ dan $1986 \mathrm{M}$.

Khainuddin. "As-Shifa' Perspektif Tafsir al-Ibris Karya Bisri Mustofa", Tribakti: Jurnal Pemikiran Keislaman, Vol. 30, No. 1, 2019.

Ma'luf, Louis. al-Munjid fì al-Lughah. Beirut: Dār al-Mashriq, 1977.

Marzuki. "Suwuk sebagai Pengobatan Tradisional pada Etnis Jawa di Desa Naga Jaya I Kecamatan Bandar Huluan Kabupaten Simalungun”. Skripsi--Universitas Negeri Medan, Medan, 2019.

Mubārak, Abū 'Ubaydah Māhir b. Șaliḥ 'Alī. Ruqyah Syar'iyyah: Gangguan Jin, Hasad, dan 'Ain, terj. Abu Ahmad. Surabaya: Duta Ilmu, 2006.

Mubāraḳfūrī (al), Abū al-Ḥasan 'Ubayd Allāh b. Muḥammad 'Abd al-Salām. Mir'ät al-Mafätīh Sharḥ Mishkät al-Masābiḥ, Vol. 5. Benaris al-Hind: Idārat al-Buhūth al-'Ilmīyah wa al-Da'wah wa al-Iftā', 1984.

Munawwir, Ahmad Warson. Kamus Al-Munawnir Arab-Indonesia Terlengkap. Surabaya: Pustaka Progresif, 1984. 
Naysābūrī (al), Abū al-Husayn Muslim b. al-Hajijāj b. Muslim alQushayrī. al-Jāmi' al-Sahīh Saḅ̄h Muslim, Vol. 4, 7, ed. Muhammad Fu'ād 'Abd al-Bāqī. Beirut: Dār al-Āfāq al-Jadīdah, t.th.

Qahtạn̄̄i (al), Sa'īd b. 'Alī b. Wahf. al-Du'à' min al-Kitäb wa al-Sunnah wa Yalīh al-Tläj bi al-Ruqà min al-Kitāb wa al-Sunnah. Riyadh: alMatāâi al-Ḥamidị, 1422.

Qazwīīi (al). Sunan Ibn Mäjah, Vol. 11. t.t.: t.tp., t.th.

Șan'ānī (al), 'Abd al-Razzāq. Tafsìr al-Qur'ān, Vol. 8. t.t.: t.tp., t.th.

Șāyim (al), Muhammad. Murshid al-Mu'älijin bi al-Qur'ān al-Karim. alQāhirah: Dār al-Fadịlah, 2006.

Shaykh (al), Șāliḥ b. 'Abd al-'Azīz b. Muḥammad b. Ibrāhīm 'Alī. al-Tambid li Sharḥ Kitäb al-Tawhìd, Vol. 1. t.t.: Dār al-Tawhịd, 2003.

Sholeh, Moh. Bertobat sambil Berobat: Rahasia Ibadah untuk. Mencegah dan Menyembubkan Berbagai Penyakit. Bandung: Hikmah, 2008.

Ṭabrānī (al), Sulaymān b. Aḥmad b. Ayyūb Abū al-Qāsim. alMu'jam al-Saghì, Vol. 2. Beirut: al-Maktab al-Islāmī, 1985 M.

Tim Penyusun. Kamus Besar Bahasa Indonesia. Jakarta: Balai Pustaka, 1989.

Tjakraningrat, Kanjeng Pangeran Harya. Kitab Primbon Betaljemur Adammakna. Yogyakarta: Soemodidjojo Mahadewa, 1980.

Wehr, Hans. A Dictionary of Modern Written Arabic. London: Macdonal \& Evans LTD, 1974.

Wibowo, Kabul. "Metode Dakwah dengan Pendekatan Ruqyah Syar'iyyah: Studi Kasus pada Majelis Zikir al-Rasuli alMuhammadiyati al-Haqmaliayati di Desa Bengbulang Kecamatan Karangpucung Kabupaten Cilacap", KOMUNIKA: Jurnal Dakwah dan Komunikasi, Vol. 13, No. 1, April 2019. 